World Lumen Congress 2021 | May 26-30, 2021 |

lasi, Romania

\title{
The Concern of Energy Companies in Obtaining and Maintaining their Sustainable Value
}

Camelia Cătălina MIHALCIUC \& Maria GROSU https://doi.org/10.18662/wlc2021/45

How to cite: Mihalciuc, C.C., \& Grosu, M. (2021). The Concern of Energy Companies in Obtaining and Maintaining their Sustainable Value. In A. Sandu (vol. ed.), Lumen Proceedings: Vol. 17 World Lumen Congress 2021 (pp. 447-464). Iasi, Romania: LUMEN Publishing House. https://doi.org/10.18662/wlc2021/45 


\title{
The Concern of Energy Companies in Obtaining and Maintaining their Sustainable Value
}

\author{
Camelia Cătălina MIHALCIUC¹, Maria GROSU²
}

\author{
Abstract
}

The last years are distinguished by increasing the awareness of companies towards sustainable business, going beyond their traditional role of providing goods and services at competitive prices to meet customer requirements. Thus, companies will have to consider the effects of their best practices on the environment and society, in order to contribute to the progress of society and the protection of the environment, the essence of sustainable development being the coexistence of economic and social relations and environmental protection by implementing economic, social and environmental objectives. We can see that every company that seeks to become sustainable must consider approaches based on sustainable business practices geared to meeting customer needs. For companies listed on the stock market, the index that stands next to each company is the one that shows the level of sustainability, through corporate sustainability, long-term value is created for sharebolders, taking into account all social factors, those related to the environment, as well as economic ones. All these considerations have led to the establishment of the general objective of the paper, through which the authors aim to explain and present the importance of sustainability/sustainable development in energy companies in conjunction with the UN guidelines on business and human rights, which will address with priority to the Sustainable Development Goals (SDGs) for 2030.

Keywords: Sustainable development, sustainable business practices, corporate sustainability, principles of sustainability, listed companies, responsible company, Sustainable Development Goals (SDGs).

\section{Introduction}

Sustainability for companies in the energy sector, as well as for other companies in other sectors of activity aware of the responsibility to the environment and to society in general, means focusing on running the

\footnotetext{
1 Faculty of Economics, Administration and Business, "Stefan cel Mare" University of Suceava, Suceava, Romania, camelia.mihalciuc@usm.ro

${ }^{2}$ Faculty of Economics and Business Administration, „Alexandru Ioan Cuza“ University of Iasi, Iasi, Romania, maria lia24@yahoo.com
} 
business responsibly, through which they are committed to respecting the environment, supporting the communities in which it operates and "trying to support the UN's sustainable development goals" (Bebbington, \& Unerman, 2018). "The goal of the 17 Sustainable Development Goals (SDGs) proposed by the UN aims to stimulate activities and actions in areas of critical importance to humanity and the planet" (United Nations, 2015) and outlines some ambitious directions for action in the next years in order to combat inequalities, eradicate poverty and protect the planet by 2030 (Nechita, 2019).

"Building a sustainable energy sector is a particularly important task, especially in the current international context of climate change, where energy policies that have a direct impact on the consumer must relate to the concept of sustainability as a key criterion "(Berheci, 2013). New measures to promote a sustainable energy market are presented in the Integrated Energy Plan, Climate Change 2021-2030, promoted in the European Union in 2019 and adopted in Romania in 2019 (Tantau\& Santa, 2019).

On the other hand, the post-2015 UN agenda is "a historic opportunity for companies to engage in a strong and positive influence on society"(World business council for sustainable development, 2018). "The implementation of sustainability actions is based on mobilizing all stakeholders around the new agenda" (United Nations, 2015) that has joined the United Nations (UN) High Level Development Policy Forum to assess progress "in line with the UN 2030 Agenda for Sustainable Development"(United Nations, 2015).

"Oil and gas companies in the energy sector are internationally recognized as one of the most economically important industries for society " (German et al., 2016),as these companies also have a significant impact on the environment, which has led them to have a concern more careful in controlling the environmental indicators they report(German et al., 2016). If we refer to the comparison of the environmental performance generated by these companies, we notice that it is difficult to achieve this comparability due to the diversity of indicators found in the sustainability reports of companies (Mihalciuc, et al., 2020).

"Global consumption of energy and environmental resources has been growing rapidly in recent decades, due to advances in the production and transport of goods, as well as the reduction of barriers to global commercial markets" (Ebubekir, et al., 2016). Focusing on technological, economic and social approaches is an appropriate approach to the sustainability of energy systems (Sáez-Martínez, et al. 2016).

Regarding the effect of the pandemic crisis in the energy sector, we can emphasize that it was uneven, as utility and service companies were less affected by the crisis and those in the oil and gas industry were more severely affected. 
Creating and protecting the value of the company calls into question the management of a different nuanced ecosystem consisting of financial, social, environmental factors, etc. (Mihalciuc\&Grosu, 2017). At present, we can note that "the COVID-19 pandemic has led to a fragility of relations in the ecosystem” (Mallovy Hicks et al., 2021).

The main objective of this paper is to review in the first direction the literature on the system of creating the sustainable value of companies in general and those in the energy sector in particular, presenting the concepts, specific terms of sustainable development of companies, and the second step taken into account in achieving the proposed objective is to investigate the situation of companies "in the energy sector listed on the Bucharest Stock Exchange" involved in sustainable development objectives required by the UN 20230 Agenda. (United Nations, 2015).

\section{Social responsibility - strategic action in ensuring and maintaining the sustainable development of companies in the energy sector}

About CSR, in general, there are numerous theoretical and applied researches in the foreign specialized literature; many of these researches present "the importance of integrating corporate social responsibility in the business strategy" (Mihalciuc \& Grosu, 2020). We can observed that the actions of corporate social responsibility must be integrated in the strategy of the company "for obtaining benefits such as: improving the corporate reputation, gaining customer trust", etc (Dey \& Sircar, 2012; Mihalciuc \& Grosu, 2020).

Most international and transnational companies have successfully integrated sustainable development into their business strategies, thus being considered corporations that promote sustainability (Diesendorf, 2000)

Through the sustainable development ensures the balance between. the human being and the environment, aiming at sustainable and inclusive economic growth, objectives based on social, environmental and economic development (Jeffrey, 2015).

To create value, a company that embraces corporate social responsibility must ensure that, in the long run, social performance and economic performance move in the same direction, and therefore the benefits of CSR outweigh the relative costs, balancing shareholders' interests in a triumphant manner. with the interests of all other stakeholders (Izzo \& Magnanelli, 2012). 
Corporate social responsibility practices implemented at the level of companies lead to increased social and environmental performance (Mihalciuc \& Apetri, 2017).

CSR is "the contribution made by an organization to sustainable economic development, based on the collaboration of stakeholders: employees, local community, suppliers, partners (Socoliuc et al., 2018). They improve their quality of life in a modern developed society" (World Business Council for Sustainable Development, 2018).

The obligations of a company attesting to the role of a socially responsible company are given by ethical behaviour and by those actions that support sustainable development, by satisfying all stakeholders and maintaining relations between them (Belascu, 2015).

Bioeconomic is a relatively recent field, and the CSR approach on "a representative segment of organizations from three important subdomains of bioeconomy", is a first and is of major interest in the literature (Androniceanu, 2019; Andronie, et al., 2019).

Sustainable business models (Richardson, 2008) take into account key elements such as how to plan for value, how to obtain value and how to acquire value (Bocken, et al., 2014) and also include those ecological models based on products or processes, those systems waste regeneration, as well as those alternative energy-based systems, those innovative financing schemes and green neighbourhoods and cities (Beltramello, Haie-Fayle\&Pilat, 2013).

"The essence of sustainable development lies in the coexistence of economic and social relations and environmental protection through the implementation of economic, social and environmental objectives, objectives that achieve issues related to human rights, cost reduction (energy and raw materials), those related to improving quality and living conditions, care for the health and safety of employees, food security, health protection, culture and education, benefits for disadvantaged groups, ways to stop the degradation of the natural environment and reduce waste and emissions into the environment" (Anastasiou\& Marietta, 2020).

Ecological objectives aim "to reduce emissions and pollution, smart use of resources, biodiversity, security ecosystems, protection of natural resources, recycling, use of organic production" (Pieloch-Babiarz, et al., 2021).

In general, "the energy sector has been perceived as a key to economic development, with a strong correlation between economic growth and expanding energy consumption, energy being a requirement in our daily lives, as a way to improve human development, leading to economic growth and productivity" (Owusu Phebe \&Asumadu-Sarkodie, 2016). 
Sustainable development under the Europe 2020 Strategy (Anastasiou \& Marietta, 2020) provides "the ability to use technologies and scientific achievements to create alternative policy proposals to ensure increased productivity, efficiency, social consistency and, of course, prudent management of natural resources ".

Applying "the principles of sustainable development" should be part of the mission of any firm to take advantage of those strategic opportunities by generating profits (Wysokińska-Senkus, 2021), sustainability is the driving force of a firm in decision making (Wicks, 1996).

\section{The matrix of sources for generating the value of a company}

Reconfiguring a company that creates sustainable value is no longer based on focusing on short-term profitability, which has often meant a longterm compromise, but involves companies "taking flexible measures and updating critical capabilities such as setting strategic direction, allocation processes of resources and governance, which together allow the implementation and recalibration of operational assets" (Mallovy Hicks, et al. 2021).

If we talk about a value creation system, it consists of three interdependent components, as can be seen in Figure 1.

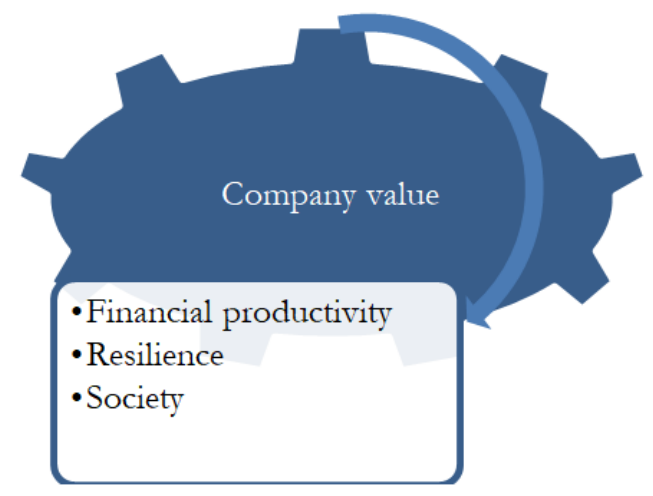

Figure 1. The value creation system .Author's own conceprion

For many companies, investing in performance increases is a way to create efficient long-term assets, by finding the right balance between costs and cost savings, and by companies' concerns about the non-financial aspects of their performance.

In terms of resilience, we can say that a resilient company can respond and adapt effectively to external shocks and can fold and develop to take advantage of new reinvention opportunities, which lead to increasing the company's value, being able to become pioneers in certain fields. and 
excelling in creating new, sustainable operational models through the combined strength of actions related to the environment, society and governance(Mallovy Hicks, et al. 2021).

The approach to involvement in society shows that a company also creates value by taking into account the various social challenges through social inclusion programs, so shareholders have a holistic view of value, focusing more and more on creating long-term value (Pasimeni, 2012).

For a company in the energy sector, the optimization of resource allocation can be done by adapting a unique value measurement system, by developing "a new value framework, which complements traditional financial measures "with mechanisms that include environmental impact, communities, customers, regulator, employee health and safety, operational innovation and resilience of the company and the supply chain.

The elements presented above converge towards "a single value matrix that allowed the company to choose in the allocation of resources and to assess the necessary trade-offs in the portfolio of activities based on a broader spectrum of value impact analysis“ (Mallovy Hicks, 2021).

We can conclude that it is important for each company to give priority in identifying the determinants of value creation. especially since we all know that the shock of the COVID-19 pandemic triggered unforeseen changes that instantly put pressure on business models and current revenues and, implicitly, on the value of the company.

\section{Research methodology}

Starting from the identification and highlighting of the latest studies and practices on sustainable reporting in the energy sector, at international level, the general objective of the paper is to make a comparative analysis of the content of sustainability reports of energy companies listed on the Bucharest Stock. Exchange on the regulated market, in terms of aligning with the sustainable development objectives found in these reports, thus identifying best reporting practices for companies operating in the energy sector.

To achieve the proposed objective of present paper, the authors analyse the information on current requirements and prospects for achieving the 17 objectives set as directions for action for sustainable development proposed by the UN, by collecting data on energy companies listed on the regulated market in Romania, reporting in an effort to support the UN's sustainable development goals.

To conduct the study, the authors used a database that includes the 11 companies in the energy sector listed on the regulated market at BSE. 
Thus, in order to organize this database, a list of criterion-variables, relevant for the purpose of the research, and interdependent tables containing relevant information extracted from the non-financial or sustainability statements and reports of these companies, referring to the objectives, principles and directions of action of "the 2030 Agenda for Sustainable Development" (United Nations, 2015).According to the specific methodology of content analysis, the approach based on descriptive statistics started first from the comparative analysis of the information contained in the database used, and later we made an explanatory description regarding the resulting trends (Jaba, 2008).

\subsection{Testing and validation of research hypotheses}

The statistical approach used starts primarily from "identifying the analyzed population and selecting the sample, choosing variables, establishing data analysis methods, data collection and processing, and finally materializing the research results, which will be analyzed and interpreted“(Jaba, 2008).

The analyzed sample includes 11 listed companies, from the energy sector for which data related to the financial year 2019 and 2020 were collected (data reported on June 30, 2020), and as can be seen from figure no. 2, depending on the object of activity, 4 companies in the sector of production and 7 companies in the services sector were identified.

\section{Sample structure of energy companies}

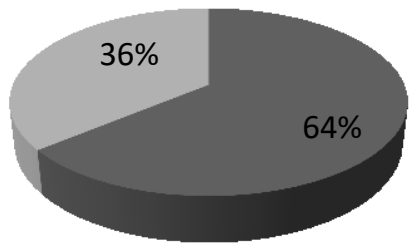

Services

Manufacturing Industry

Figure 2. Sample structure of listed companies from the energy sector.

Author's own conception 
From the above presentation it can be seen that taking into account the analyzed sample, the services in the energy sector have a significant share.

\subsection{Analyzed variables and data source}

Based on the descriptive statistics, Table 1 describes the variables identified as components of the comparative study.

Table 1. Description of the variables used



Source: The variables used represents the Sustainable Development Goals required by the 2030 Agenda (United Nations, 2015) 
Data collection was performed on the basis of sustainability reports or non-financial statements of "the companies included in the sample, using for the comparative analysis the appropriate tools for descriptive statistics" (Nuca, et al., 2020)

\section{Results and discussions}

In order to achieve the proposed research objective, qualitative variables were mainly taken into account. Thus, the variable: "Field of activity" was broken down into two directions: Manufacturing Industry and Services, and in terms of Sustainable Development Goals [29] in which the companies included in the sample were and are involved, depending on the reporting of companies in this direction the analysis was conducted on the "objectives of innovation, community, environment, employees, education, sports, health and culture "(Nuca, et al., 2020)

Regarding the variable: "Sustainable development strategy" was taken into account, two values, given that some companies only state that they are involved in sustainable development actions, without describing the actions and projects that show involvement, and another value shows companies that say they have adopted sustainable development strategies and are also involved in projects along these lines (Nuca, et al., 2020)

According to the reporting of the companies, regarding the "Management System of Quality, Environment, Health and Safety"(United Nations, 2015), all the companies in the sample have implemented such an integrated System. Given that 8 of the companies under analysis have an average of more than 500 employees, they were required to report information on "Respect for Human Rights and the Fight against Corruption"(United Nations, 2015), which is why other variables were identified with reference to these issues. These two variables cover several axes, such as "ensuring bealth and safety at work, social dialogue, non-discrimination, human development and vocational training, actions that are part of the variable given by respect for human rights," (Nuca, et al., 2020) and variables that correspond to the fight against corruption and bribery. they are focused on the existence of the "Codes of Ethics and Integrity, of the Anti-bribery Policies" (United Nations, 2015), as well as on the adherence or not of the companies to "the National Anti-Corruption Strategy 20162020“(United Nations, 2015).

Based on the comparative analysis of the BSE listed companies from energy sector, the main results present "the identification of the sustainable development strategy, the management system and involvement in actions on respect for 
buman rights and the fight against corruption, as well as the sustainable development objectives "(Table 2).

Table 2.Description of the analyzed variables

\begin{tabular}{|c|c|c|c|}
\hline The used variables & Value & $\begin{array}{l}\text { No. of } \\
\text { occurrences }\end{array}$ & $\begin{array}{l}\text { Frequency of } \\
\text { occurrence }\end{array}$ \\
\hline \multirow[t]{2}{*}{ Activity Field } & $\begin{array}{l}\text { Manufacturing } \\
\text { Industry }\end{array}$ & 4 & $64 \%$ \\
\hline & Services & 7 & $36 \%$ \\
\hline \multirow[t]{2}{*}{ "Goals in Innovation" } & Yes & 9 & $82 \%$ \\
\hline & Not & 2 & $18 \%$ \\
\hline \multirow[t]{2}{*}{ "Goals in Community" } & Yes & 8 & $73 \%$ \\
\hline & Not & 3 & $27 \%$ \\
\hline \multirow[t]{2}{*}{ "Environmental Goals" } & Yes & 11 & $100 \%$ \\
\hline & Not & 0 & $0 \%$ \\
\hline \multirow{2}{*}{ "Goals on Employees" } & Yes & 11 & $100 \%$ \\
\hline & Not & 0 & $0 \%$ \\
\hline \multirow[t]{2}{*}{ "Goals in Education" } & Yes & 8 & $73 \%$ \\
\hline & Not & 3 & $27 \%$ \\
\hline \multirow[t]{2}{*}{ "Goals in Sports" } & Yes & 6 & $55 \%$ \\
\hline & Not & 5 & $45 \%$ \\
\hline \multirow[t]{2}{*}{ "Goals in Health" } & Yes & 8 & $73 \%$ \\
\hline & Not & 3 & $27 \%$ \\
\hline \multirow[t]{2}{*}{ "Goals in Culture" } & Yes & 4 & $36 \%$ \\
\hline & Not & 7 & $64 \%$ \\
\hline \multirow[t]{10}{*}{ Goals Number per companies } & Goals - 0 & 0 & $0 \%$ \\
\hline & Goal-1 & 0 & $0 \%$ \\
\hline & Goals - 2 & 1 & $10 \%$ \\
\hline & Goals - 3 & 2 & $18 \%$ \\
\hline & Goals - 4 & 0 & $0 \%$ \\
\hline & Goals - 5 & 0 & $0 \%$ \\
\hline & Goals - 6 & 2 & $18 \%$ \\
\hline & Goals - 7 & 3 & $27 \%$ \\
\hline & Goals - 8 & 3 & $27 \%$ \\
\hline & Total & 11 & \\
\hline "Sustainable Development & Declared and & 7 & $64 \%$ \\
\hline Strategy" & $\begin{array}{l}\text { Involved } \\
\text { Declared }\end{array}$ & 4 & $36 \%$ \\
\hline $\begin{array}{l}\text { "Quality, Environment, Health } \\
\text { and Safety Management System" }\end{array}$ & $\begin{array}{l}\text { Integrated } \\
\text { System }\end{array}$ & 11 & $100 \%$ \\
\hline "Occupational Safety and & Yes & 11 & $100 \%$ \\
\hline Health $(\mathrm{OSH})$ " & Not & 0 & $0 \%$ \\
\hline "Social Dialogue" & Yes & 8 & $73 \%$ \\
\hline
\end{tabular}




\begin{tabular}{|c|c|c|c|}
\hline \multirow[t]{2}{*}{ The used variables } & Value & $\begin{array}{l}\text { No. of } \\
\text { occurrences }\end{array}$ & $\begin{array}{l}\text { Frequency of } \\
\text { occurrence }\end{array}$ \\
\hline & Not & 3 & $27 \%$ \\
\hline \multirow[t]{2}{*}{ "Non discrimination" } & Yes & 8 & $73 \%$ \\
\hline & Not & 3 & $27 \%$ \\
\hline "Human development and & Yes & 8 & $73 \%$ \\
\hline professional training" & Not & 3 & $27 \%$ \\
\hline \multirow[t]{2}{*}{ "Code of Ethics and Integrity" } & Yes & 8 & $73 \%$ \\
\hline & Not & 3 & $27 \%$ \\
\hline \multirow[t]{2}{*}{ "Anti-Corruption Policies" } & Yes & 8 & $73 \%$ \\
\hline & Not & 3 & $27 \%$ \\
\hline "Declaration of Adherence to the & Yes & 4 & $36 \%$ \\
\hline $\begin{array}{l}\text { National Anti-Corruption } \\
\text { Strategy 2016-2020" }\end{array}$ & Not & 7 & $64 \%$ \\
\hline
\end{tabular}

Author's own conception

We thus observe that the data in table no. 2 lead us to the appreciation that the "Integrated Quality, Environment, Health and Safety Management System "is implemented by all companies in the analysed sample, $36 \%$ of the analysed companies have joined the National Anticorruption Strategy 2016-2020, and in regarding the and regarding the sustainable development objectives found in the content of the sustainability reports we can observe the following situation: a number of three companies have provided in the sustainable development strategy 3 or 2 goals, 2 companies have a number of 6 objectives implemented, but a number of six companies are involved in 7 or 8 sustainable development goals.

A graphical highlighting of the comparative study in terms of sustainable development goals for the companies subject to analysis can be viewed in figures no. 3 a) and $3 \mathrm{~b}$ ). 


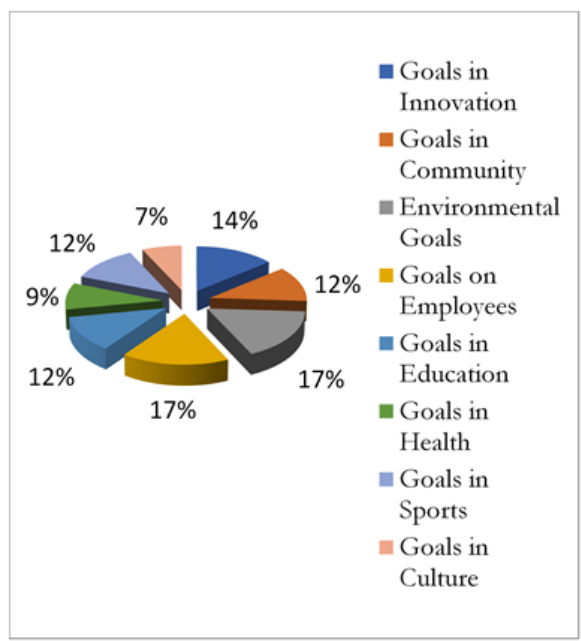

a)

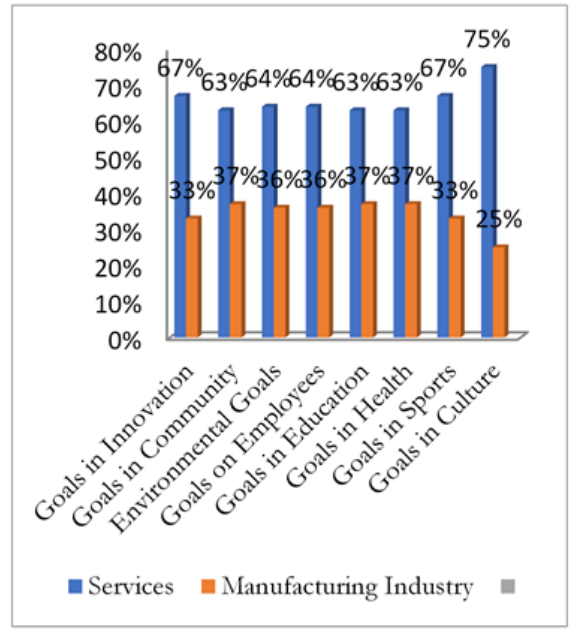

b)

Figure 3. Companies in the energy sector involved in sustainable development goals. Author's own conception

From the previous table and from figures 3 a) and 3 b) it can be seen that the companies operating in the field of services have the highest share, for all the objectives of sustainable development, and among the objectives of sustainable development are highlighted the environmental objectives and those of employees, in a percentage of $17 \%$, followed by innovationoriented goals at $14 \%$, as well as those aimed at education, sports and the community, in percentage of $12 \%$. At the level of the analysed sample. The lowest shares are held by health-oriented $(9 \%)$ and culture-oriented $(7 \%)$ sustainable development goals.

For the Sustainable Development Strategy, depending on the reporting made by the analysed companies, the two values can be observed in figure no. 4. 




Figure 4. Sustainable development strategy in terms of how to declare and involve companies in the energy sector. Author's own conception

From figure no. 4 it is noted that, with regard to the sustainable development strategy, only 37\% say that they have adopted such a strategy in the case of energy-producing companies, while 38\% are involved in sustainable development projects for various purposes, and for energy service companies, 67\% only declare and 63\% of them declare and are also involved in sustainable development projects.

For the other guidelines that converge with the directions of the 2030 Agenda, the analysis led to the following data briefly highlighted in the next figures (figures $5 \mathrm{a}$ and $5 \mathrm{~b}$ ). 


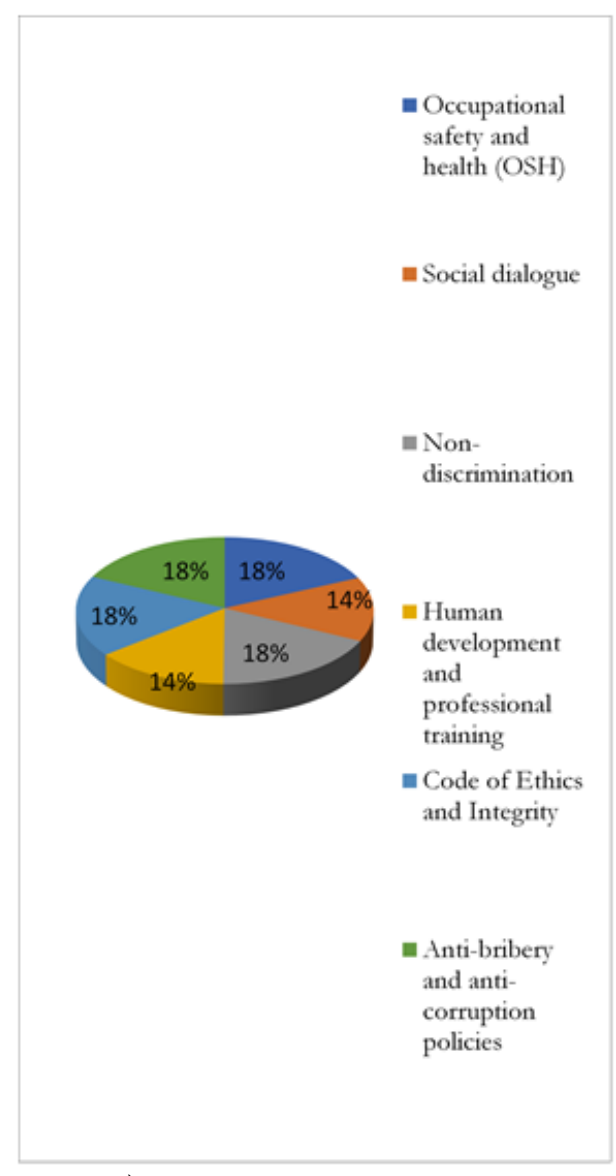

a)

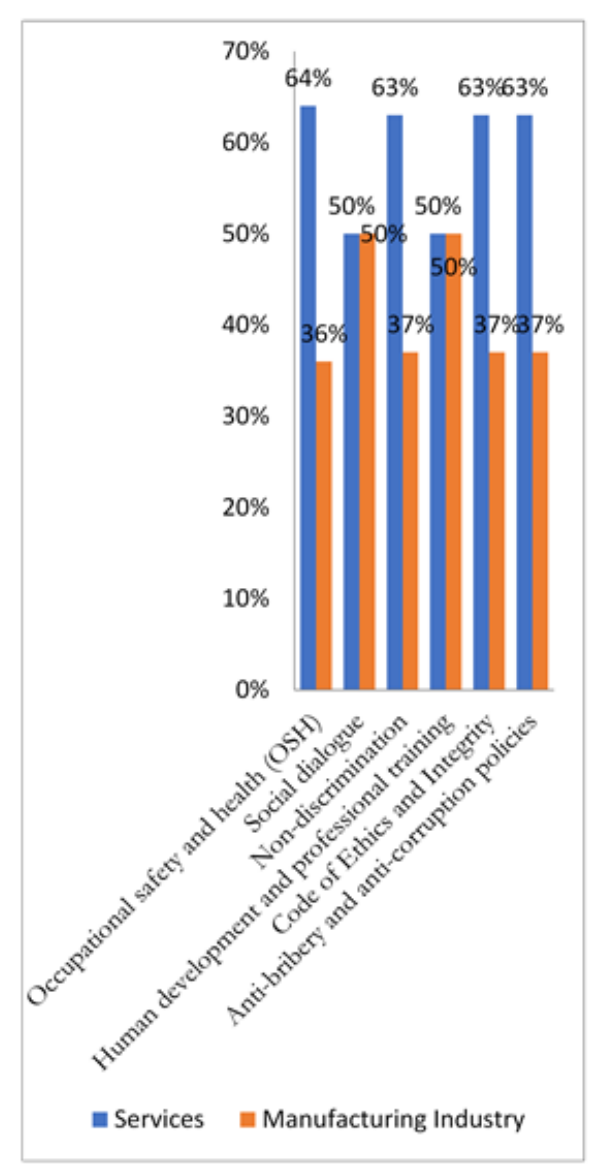

b)

Figure. 5. Involvement in other directions of sustainable development of companies in the energy sector. Author's own conception

From figure no. 5 a) and 5 b) it can be seen that for the sampled companies, the distribution on the two areas of services and production in the energy sector indicates that the field of services in this sector has the highest percentage related to other directions of sustainable development. For all these directions considered at the time of reporting, 18\% are allocated to reporting actions "on ensuring bealth and safety at work, nondiscrimination, combating corruption and bribery" as well as reporting the subsistence of "codes of ethics and integrity", and 14\% represent reports focused on "social dialogue" and also on "buman development and professional training". 


\section{Conclusions}

The current epidemiological situation, together with the dynamics of the international crude oil markets, respectively the uncertainties regarding the regulations on the Romanian market contribute to highlighting an unfavourable market environment corresponding to many companies operating in the energy sector. The environment in which companies operate in the energy sector is a complex one, so it is necessary to identify, classify and prioritize stakeholders on the one hand, and on the other hand these companies must continue to support the concept of responsible business, focusing on increasing the culture of sustainability, in order to use natural resources in an efficient way, and to have high safety and environmental standards, and for common long-term growth.

From the comparative analysis performed and from a previous study [20], we can appreciate that the companies in the energy sector on BVB are involved in the sustainable development strategy, through various integrated management systems implemented within these companies. We also appreciate that these companies are initiating actions on respect and the fight against corruption and bribery, thus becoming sustainable, by designing and using sustainable business practices anchored in the Sustainable Development Goals of the 2030 Agenda [29], thus, these companies are in the profile of sustainable companies, concerned to maintain their value sustainable.

From the study conducted in this paper, we can conclude that most companies in the energy sector are involved in actions to support sustainable development, adopting sustainable development strategies, thus identifying based on the comparative analysis the number of development objectives achieved by BSE-listed companies operating in this sector. We can thus note that through a sustainable behaviour adopted by companies, value is added to them, thus creating the overall image of the sustainable company, which includes the economic, social and environmental pillars.

\section{References}

Anastasiou, A., \& Marietta, P. (2020). Sustainable Development at the Frames of the Strategy "Europe 2020". Theoretical Economics Letters, 10, 443-457. https://doi.org/10.4236/tel.2020.103028

Androniceanu, A. (2019). Social Responsibility, an Essential Strategic Option for a Sustainable Development in the Field of Bio-Economy. Amfiteatru Economic, 21(52), 503-519. https://doi.org/10.24818/EA/2019/52/503 
Andronie, M., Simion, V.E., Gurgu, E., Dijmărescu, A., \& Dijmărescu, I. (2019). Social Responsibility of Firms and the Impact of Bio-Economy in Intelligent Use of Renewable Energy Source. Amfiteatru Economic, 21(52), 520-535. https://doi.org/10.24818/EA/2019/52/520

Bebbington, J., \&Unerman, J. (2018). Achieving the United Nations Sustainable Development Goals An enabling role for accounting research. Accounting, Auditing and Accountability Journal, 31(1), 2-24. https://doi.org/10.1108/AAAJ-05-2017-2929

Belaşcu, L. (2013). Responsabilitatea corporativă şi performanțele companiilor multinaționale, in Studii post-doctorale în economie”, volumul 5, Studii și cercetări privind impactul globalizării asupra structurii și dinamicii economiilor [Corporate responsibility and the performance of multinational companies, in Post-doctoral studies in economics ", volume 5, Studies and research on the impact of globalization on the structure and dynamics of economies] (Publication No. 978-973-272295-4) [Doctoral dissertation]. Romanian Academy Publishing House.

Beltramello, A., Haie-Fayle, L., \&Pilat, D. (2013). Why new business models matter for green growth.OECD Green Growth Papers 1. https://doi.org/10.1787/5k97gk40v3ln-en

Diesendorf, M. (2000). Sustainability and sustainable development. In D. Dunphy, J. Benveniste, A. Griffiths, \& P. Sutton, (eds.), Sustainability: The corporate challenge of the 21st (pp. 19-37). Allen \& Unwin.

Berheci, M. (2013). Corporate responsibility and performance of multinational companies [Unpublished Post-Doctoral Dissertations, Romanian Academy].

Bocken, N.M., Short, S.W., Rana, P., \& Evans, S. A. (2014). Literature and practice review to develop sustainable business model archetypes. Journal of Cleaner Production, 65, 42-56. https://doi.org/10.1016/i.jclepro.2013.11.039

Dey, M., \& Sircar, S. (2012). Integrating Corporate Social Responsibility Initiatives with Business Strategy: A Study of Some Indian Companies. The IUP Journal of Corporate Governance 11(1), 36-51. https://papers.ssrn.com/sol3/papers.cfm?abstract id=2148237

Germán, A., Wolfgang, F., Gerstlberger, J., Bonzanini, A., Bernardi, D., \& Pedrini, C. (2016). An integrative environmental performance index for benchmarking in oil and gas industry. Journal of Cleaner Production, 133, (1), 1190-1203. https://doi.org/10.1016/i.jclepro.2016.06.064

Izzo, F., \& Magnanelli, B.S. (2012). Does it pay or does firm pay? The relation between CSR performance and the cost of debt. SSRN Electronic Journal 145. https://doi.org/10.2139/ssrn.1986131

Jaba, E. (2008). Econometrie aplicată. Alexandru Ioan Cuza Publishing House. Jeffrey, S. (2015). The Age of Sustainable Development. Columbia University Press. 
Mallovy Hicks, H., Gilcreast, A., Marais, H., \& Manning, C. (2021). The drivers of enterprise value extend beyond financial productivity and as dismption intensifies, businesses must adapt to avoid value destruction. Strategy+BUSINESS.

https://www.strategy-business.com/article/A-CEO-guide-to-todays-valuecreation-ecosystem

Mihalciuc, C. C., Grosu, M., \& Apetri, A. N. (2020). Supporting the Sustainable Development of Companies Through the Use of Social Responsibility Practices In International Affairs. LUMEN Proceedings, 13, 206-225. https://doi.org/10.18662/lumproc/ncoe4.0.2020/19

Mihalciuc, C. C., \& Grosu, M. (2020). Sustainable business practices and corporate models, European Finance, Business and Regulation EUFIRE. Alexandru Ioan Cuza Publishing House.

Mihalciuc, C., \& Apetri, A.(2017). The Role of Social and Environmental Information in Assessing the Overall Performance of the Enterprise. In W. L. Filho, D. M. Pociovalisteanu, A. Q. Al-Amin, Sustainable Economic Development: Green Economy and Green Growth, (pp. 213-231). Springer International Publishing.

Nechita, E. (2019). Analysis of the Relationship between Accounting and Sustainable Development. The Role of Accounting and Accounting Profession on Sustainable Development. The Audit Financial Journal, 17(155), 520-536. https://doi.org/10.20869/AUDITF/2019/155/021

Nucă, D., Grosu, M., Mihalciuc, C., \& Apetri, A. (2020). The Identification of the Company Profile Listed on the Romanian Stock Exchange Involved in CSR Actions. In: J. Xu, G. Duca, S. Ahmed, F. García Márquez, A. Hajiyev, (eds.), Proceedings of the Fourteenth International Conference on Management Science and Engineering Management: vol. 1190, International Conference on Management Science and Engineering Management. Springer. https://doi.org/10.1007/978-3-030-49829-0_40

Owusu Phebe, A., \& Asumadu-Sarkodie, S. (2016). A review of renewable energy sources, sustainability issues and climate change mitigation. Cogent Engineering, 3(1). https://doi.org/10.1080/23311916.2016.1167990

Pasimeni, P. (2012). Measuring Europe 2020: A New Tool to Assess the Strategy. International Journal of Innovation and Regional Development, 4(5), 365-385. https://doi.org/10.1504/IJIRD.2012.048986

Pieloch-Babiarz, A., Misztal, A. \&Kowalska, M. (2021). An impact of macroeconomic stabilization on the sustainable development of manufacturing enterprises: the case of Central and Eastern European Countries. Environ Dev Sustain, 23, 8669-8698. https://doi.org/10.1007/s10668-020-00988-4

Richardson, J. (2008). The business model: an integrative framework for strategy execution, Strateg. Change, 17(5-6), 133-144. https://doi.org/10.1002/jsc.821 
Sáez-Martínez, F.J., Lefebvre, G., Hernández, J.J., Clark, J.H. (2016). Drivers of sustainable cleaner production and sustainable energy options. Journal of cleaner production, 138, 1-7. https://doi.org/10.1016/j.jclepro.2016.08.094

Ebubekir, S. S., Bayram, I. S., \& Koc, M. (2019). Demand side management opportunities, framework, and implications for sustainable development in resource-rich countries: Case study Qatar. Journal of cleaner production, 241. https://doi.org/10.1016/j.jclepro.2016.08.094

Socoliuc, M., Grosu, V., Hlaciuc, E. \& Stanciu, S. (2018). Analysis of Social Responsibility and Reporting Methods of Romanian Companies in the Countries of the European Union. Sustainability, 10(12), 4662. https://doi.org/10.3390/su10124662

Tanţău, A. \& Şanta, A.M.I. (2019). Best Practices for a Sustainable Energy Sector at European Union Level- Chances and Challenges for Romania. Amfiteatru Economic, 21(52), 697-706. https://doi.org/10.24818/EA/2019/52/697

United Nations. (2015). The 2030 Agenda for Sustainable Development. Transforming our World: The 2030 Agenda for Sustainable Development. Sustainable Development Knowledge.

https://sustainabledevelopment.un.org/post2015/transformingourworld/ publication

Wicks, A.C. (1996). Overcoming the separation thesis: The need for a reconsideration of business and society research. Sage Journals, 35(1), 89118. https://doi.org/10.1177/000765039603500108

World Business Council for Sustainable Development. (2018). Reporting Matters Six years on: the state of play. WBCSD. https://docs.wbcsd.org/2018/10/Reporting Matters 2018.pdf

Wysokińska-Senkus, A. (2021). Determinants of Improving the Strategy of Sustainable Energy Management of Building Sustainable Value for Stakeholders-Experience of Organizations in Poland. Energies, 14(10), 2878. https://doi.org/10.3390/en14102878 